\title{
LOSS OF NATURAL HERITAGE FROM THE GEOMORPHOLOGICAL PERSPECTIVE - DO GEOMORPHIC PROCESSES SHAPE OR DESTROY THE NATURAL HERITAGE?
}

Blaž Komac, Matija Zorn, Bojan Erhartič

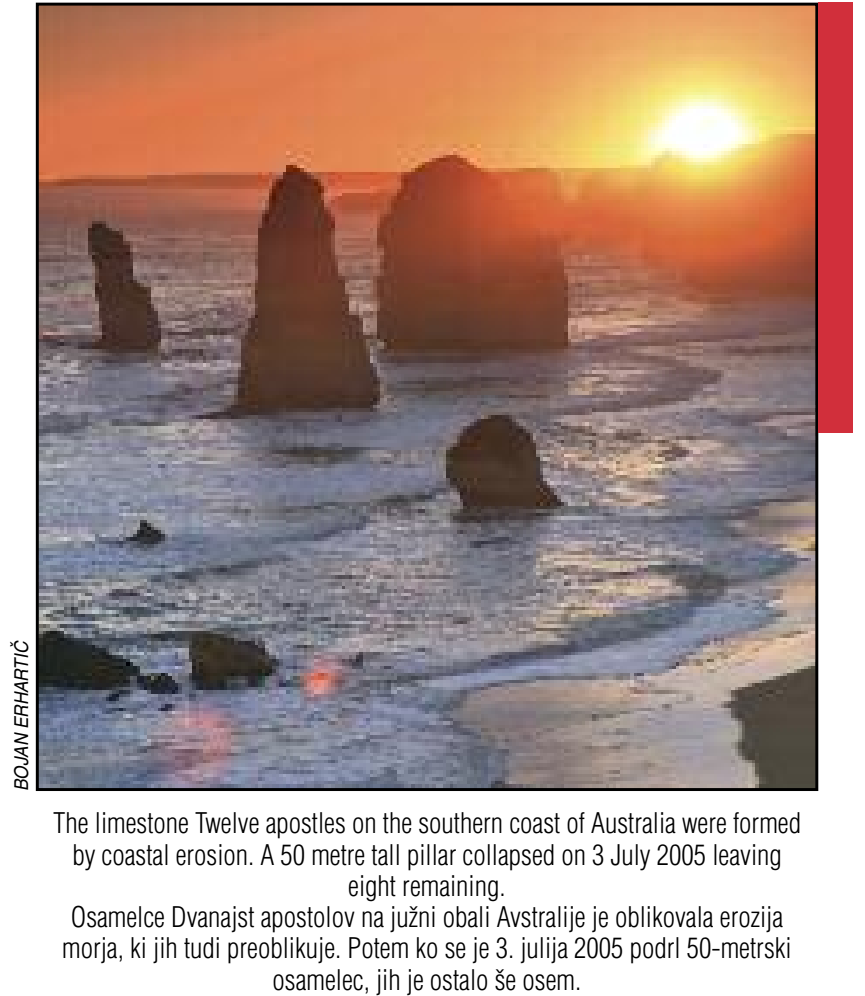




\section{Loss of natural heritage from the geomorphological perspective - Do geomorphic processes shape or destroy the natural heritage?}

DOI: $10.3986 / A G S 51305$

UDC: $911.2: 551.4(497.4)$

COBISS: 1.01

ABSTRACT: This study deals with geomorphological natural features (geomorphosites) relative to the natural processes that create, shape, or destroy such features. As a rule, geomorphologic processes are geographical constants in the landscape although some, due to their high magnitude or low frequency of occurrence, can be perceived as an exception (e.g., natural disasters).

The importance of geomorphosites is relative to their size, rarity (spatial distribution), and duration (existence in time), which depend on both the frequency and magnitude of geomorphological processes and on the standards of the observer. Human influence and perception of geomorphosites is also important in this regard.

KEY WORDS: geography, geomorphology, geomorphosites, geomorphic processes, relief forms, spatial scale, temporal scale, natural heritage, Slovenia

The article was submitted for publication on August 21, 2011.

\section{ADDRESSES:}

Blaž Komac, Ph. D.

Anton Melik Geographical Institute

Scientific Research Centre of the Slovenian Academy of Sciences and Arts

Gosposka ulica 13, SI - 1000 Ljubljana, Slovenia

E-mail: blaz.komac@zrc-sazu.si

Matija Zorn, Ph. D.

Anton Melik Geographical Institute

Scientific Research Centre of the Slovenian Academy of Sciences and Arts

Gosposka ulica 13, SI - 1000 Ljubljana, Slovenia

E-mail: matija.zorn@zrc-sazu.si

Bojan Erhartič, Ph. D.

Anton Melik Geographical Institute

Scientific Research Centre of the Slovenian Academy of Sciences and Arts

Gosposka ulica 13, SI - 1000 Ljubljana, Slovenia

E-mail: bojaner@zrc-sazu.si

\section{Contents}

1 Introduction 409

2 Geomorphosites - a matter of spatial and temporal scale

Formation and transformation

of geomorphosites - a matter

of perception?

Some examples from Slovenia $\quad 411$

Conclusion $\quad 415$

References $\quad 416$ 


\section{Introduction}

Since geomorphic processes are a relatively constant feature from the physical point of view but relief forms are not, as they are constantly (trans)formed by geomorphic processes, we wish to protect geomorphosites from the effects of the processes. We want to preserve geomorphosites and extend their existence for various reasons, among others for their aesthetic value and economic significance (Panizza 2001). This is normally accomplished through protection from human impact (too many visitors) and from natural processes (e.g., erosion).

The importance of geomorphosites (Erhartič 2010) is relative to their size, rarity (spatial distribution), and duration (existence in time), which depend on the frequency and magnitude of geomorphological processes and on the standards of the observer (Wolman and Miller 1960; Hungr et al. 2008). Thus the importance of geomorphosites is not only related to their scientific value but also to other values that allow the study of geomorphological heritage to be integrated with other fields of research, such as economy, cultural and ecological heritage (Reynard 2005; Reynard and Coratza 2007; Reynard et al. 2007).

In this endeavour it is essential to determine goals: do we wish to preserve the current situation and »conserve« nature or do we wish to preserve the processes and thereby consent to change, even if -in a long term view- it means the inevitable destruction of geomorphosites. We can certainly preserve the situation with technical and other measures, but the question is whether this is sensible since we are not so much protecting nature as trying to please man. In the article, we will describe the dilemma from the view point of natural processes on one hand and from the view point of human perception on the other, and present some examples from Slovenia.

Does preservation of geomorphosites mean that we should allow all natural processes and protect them only from unnecessary human intervention. Or should we also protect geomorphosites from the processes that had formed them as well? Often, geomorphosites are valuable and interesting precisely due to their changeability, which is due to the processes that are (re)shaping them. When the processes cease, and other prevail, the relief form can be lost.

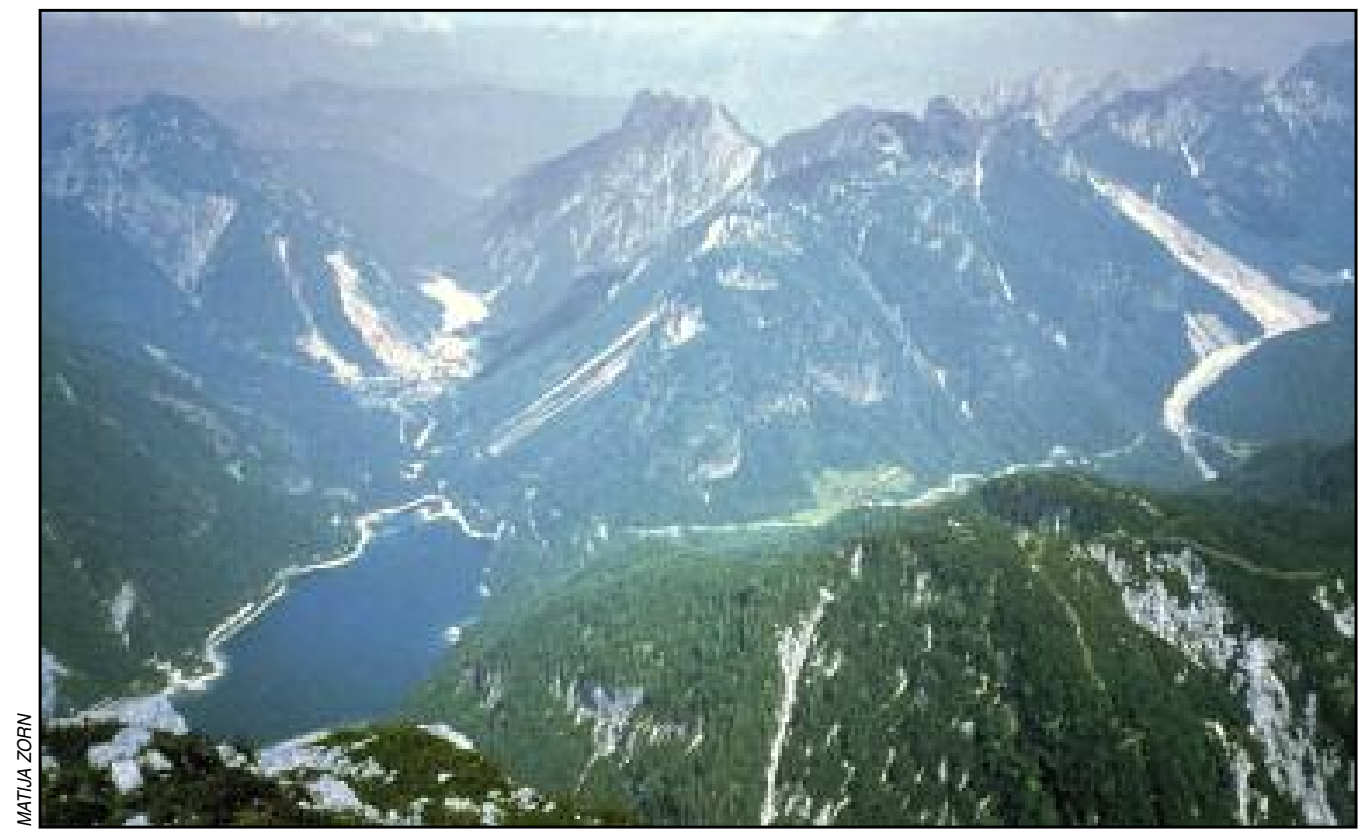

Figure 1: Long-lasting activity of lead and zinc mining (left) and an extreme geomorphic event (a landslide; right) have produced similar visual effect in the Alpine landscape, Julian Alps, western Slovenia. 


\section{Geomorphosites - a matter of spatial and temporal scale}

Geomorphosites are relief forms with an added value. They are seen as »... landforms to which a value can be attributed ... " (Panizza 2001, 4) and have three main characteristics that may be considered as a specific to them: the aesthetic dimension, the dynamic dimension and the imbrication of scales (Reynard 2009).

In this article we focus on the dynamic dimension of geomorphosites. Geomorphosites are not a stable feature but a dynamic one as an integral part of the Earth system. As noted above, the dynamism can be accelerated or slowed down by human intervention.

Relief forms are formed and transformed by natural processes. In the long run, depending on the changes of climate and other factors, different processes may operate on the same place (Batty 1997; Batty and Cole 1997) and also similar processes may lead to different relief types (Hrvatin and Perko 2009). It then follows that a geomorphosite that was shaped by an identifiable and distinct geomorphic process may be reshaped by another, different process after some time. What makes things even hard to understand (and to manage) is that different processes may overlap, operate on very different time and space scales and that they are also limited by time and space. Weathering, for example, may be limited to a specific mineral in an exposed rock and lateral erosion can be limited to certain slopes close to a river. Effects of karst weathering can be only seen after decades or hundreds of years while effects of lateral erosion can be promptly visible.

We can draw conclusions about the future development of the landscape from the relief, sedimentological, pedological, biogeographical, historical, and other evidence about processes in the past and on the basis of analyzing the current situation. A geomorphologist is particularly interested in examples of the spatial and time distribution of processes and phenomena and in this framework determines their magnitude and frequency.

A geomorphosite may be valuable exactly due to long temporal scale of the processes that had formed it: a karst cave, for example is a very stable environment and every change in it would be preserved for the next several thousand years. From the point of view of geomorphic processes, uniqueness of a geomorphosite can be also understood in temporal terms. Low magnitude-high frequency processes can leave a strong imprint in the landscape, comparable to the one left by high magnitude-low frequency events, such as landslide.

Karst process (corrosion) makes big changes in the landscape only after very long period of time (measured in millions of years), and slowly produces very stable relief forms on different spatial scales, which are often termed geomorphosites. Landslides on the other hand, usually do not form such stable relief forms, but from the time perspective of human life we can speak about landslides as »characteristic landscape features " (Radinja 1983, 68) and about landslide regions and landslide-related relief forms. The latter are only rarely termed as geomorphosites although they may be very spectacular (but they usually do not fulfil the aesthetic criteria).

Relief is a changeable environment. Geomorphic processes leave imprints on the landscape, and older layers are in most cases less distinct or visible than younger layers. The distinguishability of individual landscape elements depends on the magnitude of the processes and phenomena, on the amount of time that has passed since they occurred, and also on the ability of the system to preserve forms (Komac 2009). This is especially characteristic for karst systems. On the Kras plateau, Western Slovenia, for example, »there is a variety of (relief) forms that were formed at quite different times, but due to karst evolution, they coexist in today's relief.« (Mihevc 2007, 35).

\section{Formation and transformation of geomorphosites - a matter of perception?}

Discussing about changeable relief forms and, therefore geomorphosites we should first briefly consider geomorphic processes that shape the relief. Weathering, erosion, transport and accumulation may change existing relief forms or shape new ones (Chorley et al. 1984, 202). Weathering is one of the most important natural processes since it affects almost every material that is exposed to conditions on the contact between atmosphere, hydrosphere and biosphere (Ollier 1969). It enables geomorphic processes to 'run' and is one of the main factors in shaping the landscape. It is influenced by both, endogenic factors, such as rock properties, and by exogenic factors (Sparks 1972; Caine 1979). We may describe it as a uniform 
process, but a division to physical, chemical and biogenic has been common. From the view point of geomorphosites, physical weathering is very important - the most spectacular geomorphosites have been formed by it (e.g. rock walls, isolated rocks, cliffs). Chemical weathering is important due to its linkage with karst phenomena. It differs from physical weathering since it relatively uniformly affects the surface (Ford and Williams 1996) and also operates in depth, leading to formation of karst caves. Biochemical weathering is influenced by action of plants, and may be both, physical (e.g. by roots) or chemical (e.g. by acids). The long-term effect of animals, such as ants or cows (Trimble and Mendel 1995) on relief formation should not be neglected.

Weathering produces rock material and makes it prone to erosional-denudational processes that depend on different agents, such as gravity, water, ice and air. Next to weathering, erosional-denudational processes are usually the most important factor in changing the geomorphosites. They range from slow processes (denudation on levelled surface) to very intensive ones, such as gully and river erosion, debris flows and landslides, and from minor scale (e.g. karren) to large scale (e.g. valley formation). Although they mainly depend on natural factors, such as rainfall intensity or regolith characteristics, they may be a manageable factor since they are tightly related to human interference, especially through land use.

Accumulation processes characterize landscape evolution and contribute to considerable changes of geomorphosites in many cases, for example by covering them with sediments.

Human-induced processes have strongly influenced relief, especially in the last few centuries. In this era, the perception of the Earth, relief forms (geomorphosites), and geomorphic processes has changed a lot. Before the age of enlightenment, a theocentric relationship of man to nature prevailed, but then the man's perception of nature relativized and subsequently objectivized in modern times (Lewis 1998). The desire to eradicate the impacts of natural processes where these processes are the principal element of the landscape is one of the consequences of the objectivized perception of nature. As a result, man (in)deliberately causes long-term changes (e.g. climate change) in the natural system that he can neither perceive nor monitor at first, let alone measure or predict, by accelerating or slowing down the natural processes. In the future, however, the changed natural processes can have a negative impact on geomorphosites. It usually takes a long time for human interventions to cause changes in a landscape, and it is therefore often difficult to determine a direct causal connection between the interventions and the consequential natural processes and relief forms or geomorphosites.

\section{Some examples from Slovenia}

In the next paragraphs we will describe a few examples of Slovenia that show all the complexity of the matter. We present several cases from Slovenia, describing the coastal cliffs and conglomerate terraces, chutes and canyons, waterfalls, and a glacier.

A geomorphosite can lose or gain on additional value with the help of natural processes (Reynard etal. 2007). The example can be seen on Figure 2 with Pleistocene conglomerate river terrace as a geomorphosite per se (Komac and Zorn 2007). In 1998 the terrace was partly »damaged « by an earthquake (Vidrih, Ribičič and Suhadolc 2001) when a rockfall occurred. Terrace as a primary geomorphosite was given additional value by an earthquake induced rockfall.

The opposite was the case when an »exceptional« natural heritage was partly destroyed. The Čedca waterfall (Jezersko, N Slovenia) represents a geomorphological and hydrological heritage of national importance (Ramovš 1983). It entirely changed its own appearance during the two big rockfalls and several smaller rockfalls in 2008 (Erhartič and Jelenko 2009). Rockfalls caused many disturbances in natural environment (Figure 3). Although some claim that we lost our national heritage with the collapse of the highest waterfall in Slovenia $(130 \mathrm{~m})$, the waterfall still exists despite it is no longer so high as it was before the collapse. This example shows that the only continuity is the continuity of hydro-geomorphic processes.

Another example are flysch coastal cliffs at the Adriatic Sea coast (SW Slovenia). Geomorphic processes constantly reshape them, the cliffs retreat for few centimetres per year (Zorn 2009). Due to constant abrasion they preserve their shape by parallel rockwall retreat (Savigear 1952). In some cases the cliffs were "preserved « by building a hotel that is attached to the rockwall, or by building the buttresses below the Piran church (Figure 4) in the past centuries, which now regarded as cultural heritage. In this way a geomorphosite can be preserved from natural processes, but at the same time the geomorphosites are not visible anymore. 


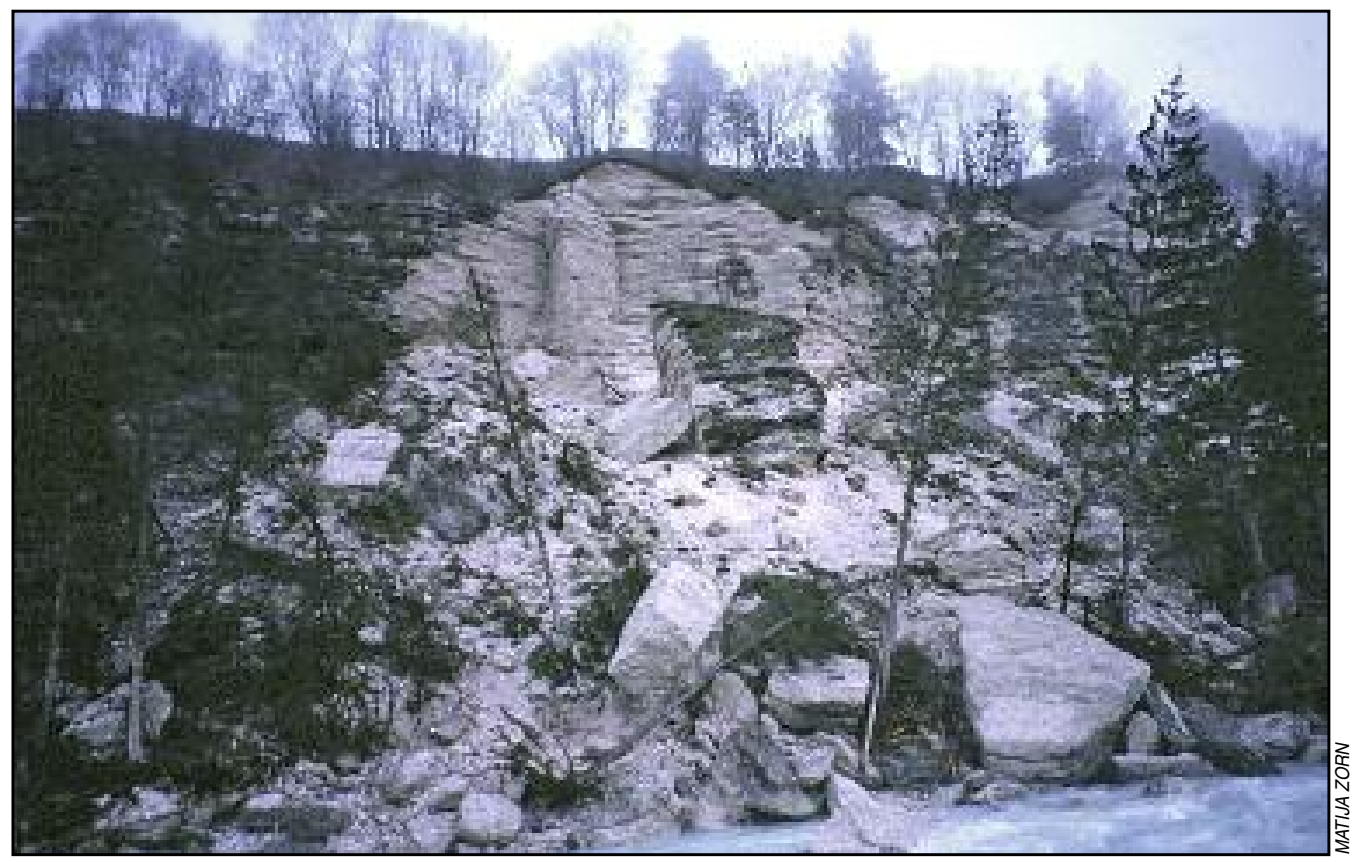

Figure 2: A earthquake-induced rockfall changed the face of a conglomerate cliff.

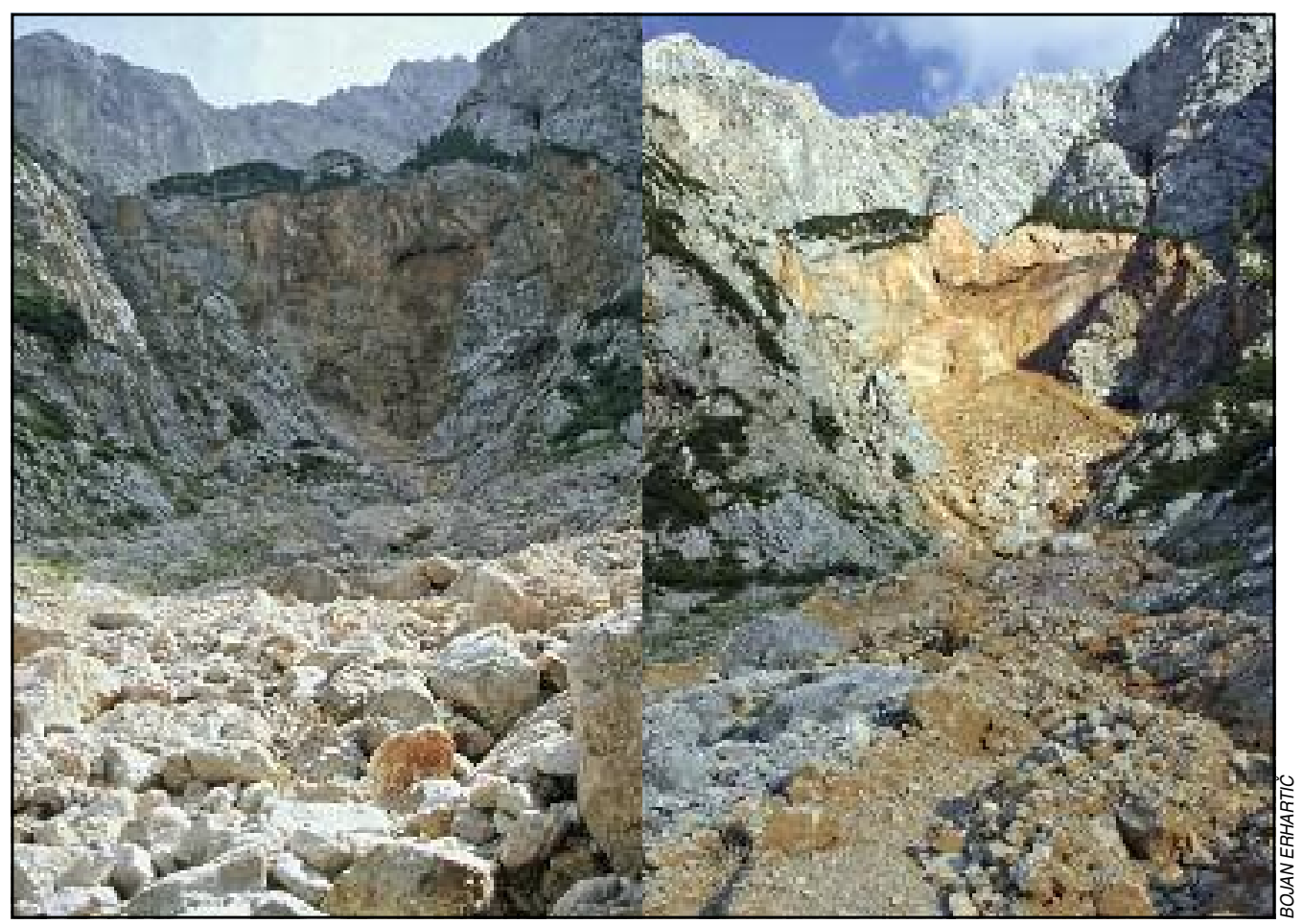

Figure 3: The Čedca waterfall before and after the collapse. 


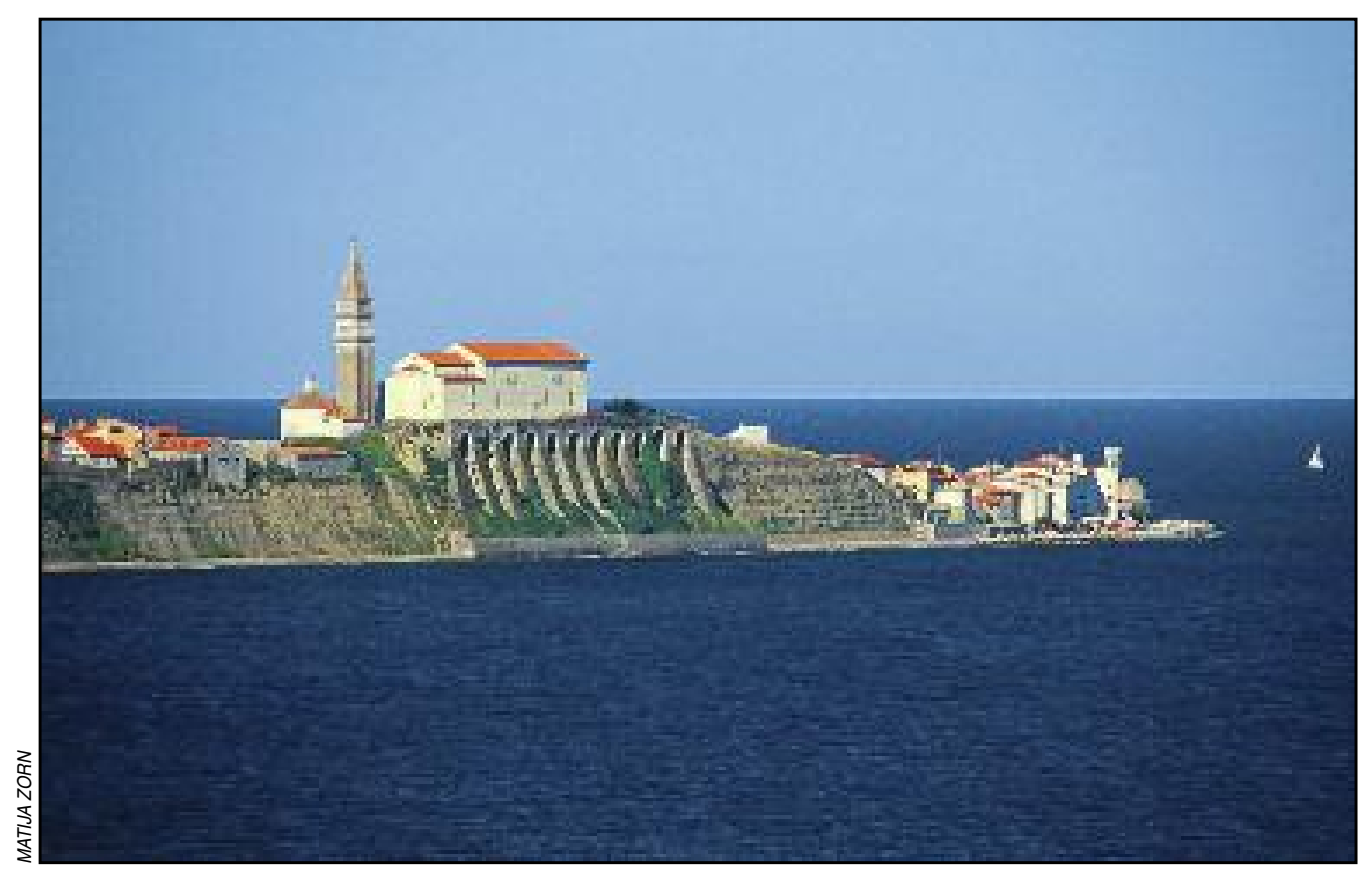

Figure 4: Picturesque flysch coastal cliffs coexist with some of the attempts to preserve the cultural heritage.

Another interesting issue connected to this is the contribution of human-induced processes to for example fluvial denudation processes. In the Upper Soča valley (NW Slovenia), studies have uniformly established that the human impact has been far greater in modern times than in past historical periods (Zorn and Komac 2008). In the long run their long-term effect is comparable to effects of natural processes (Beresford-Jones et al. 2009). Analyses of the rate of sedimentation in the seas in past geological periods and in modern times have revealed that soil erosion caused by man is ten times greater than natural soil erosion occurring without human influence (Wilkinson 2004) and that the influence of intensive human activity in the last centuries is considerable (see for example Mihevc 2000; Komac 2009).

Rockfalls are common phenomena in the Slovenian Alps. In the last decades it has been figured out that they are often triggered by earthquakes which occurred in 1976, 1998, and 2004. In this area earthquake-induced rockfalls and rainfall-induced landslides release sediment in excess of about $125,000 \mathrm{~m}^{3} / \mathrm{km}^{2}$ annually (Mikoš, Fazarinc and Ribičič, 2006) i.e. about twelve times higher comparing to average sediment production in the area (Zorn and Komac 2009). These processes also affect geomorphosites, such as chutes and gorges. In 2004 a rockfall in the Tolminka valley dammed the river (Komac and Zorn 2009). A thermal spring on the bank of the Tolminka river was covered with sediments. Although there are quite a few such springs in NE Slovenia, they are very rare in the Julian Alps. For this instance the Tolminka thermal spring was declared as a natural heritage of national importance.

Other geomorphic features are related to denudation processes influenced by man. Such are isolated rocks in the Slovenian Dinaric karst regions that became uncovered due to burning down of forests in the $1^{\text {st }}$ millennium B.C. In the later periods farmers used to collect soil from the surroundings of dolines and concentrate it on their bottom in order to cultivate them. The nearby areas were mostly left for pastures and human-induced soil erosion caused rocks and ridges to outcrop (Figure 5). Dry walls were built from redundant stones (with density up to $11 \mathrm{~km} / \mathrm{km}^{2}$ ) while in some cases they were left to nature and form an interesting geomorphosite today (Gams 2003; Mihevc 2005).

The Triglav mountain ( $2864 \mathrm{~m}$ a.s. 1.) is the highest mountain of Slovenia. Therefore, different values have been attributed to it, expressed in mythological, historical and also geomorphological heritage. It is one of the two landscapes in Slovenia where a glacier is present. Being the south-eastern-most Alpine 


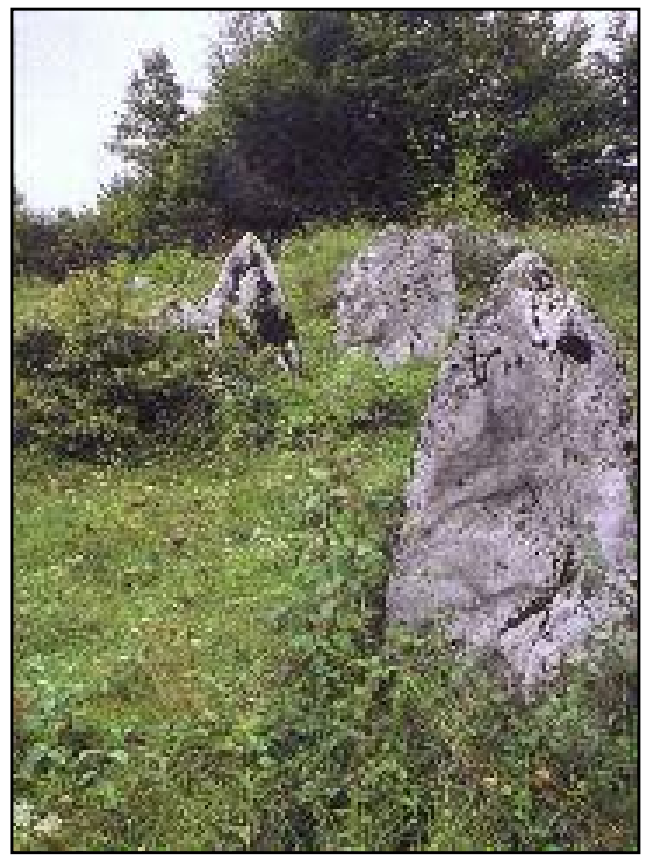

Figure 5: Isolated rocks are a common feature of the karst relief.

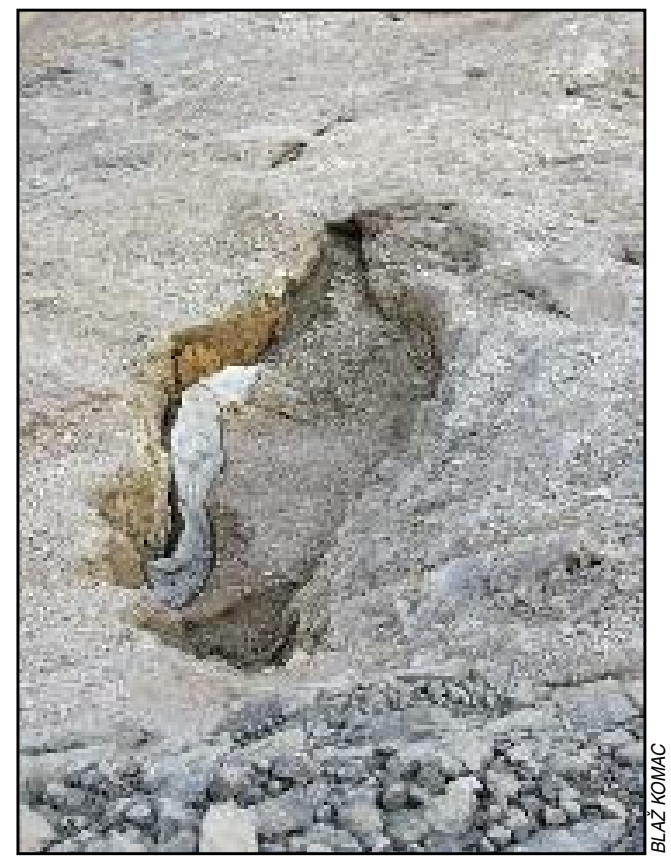

Figure 6: Subglacial landforms can only be termed geomorphosites after they have been exposed to surface by ice melting.

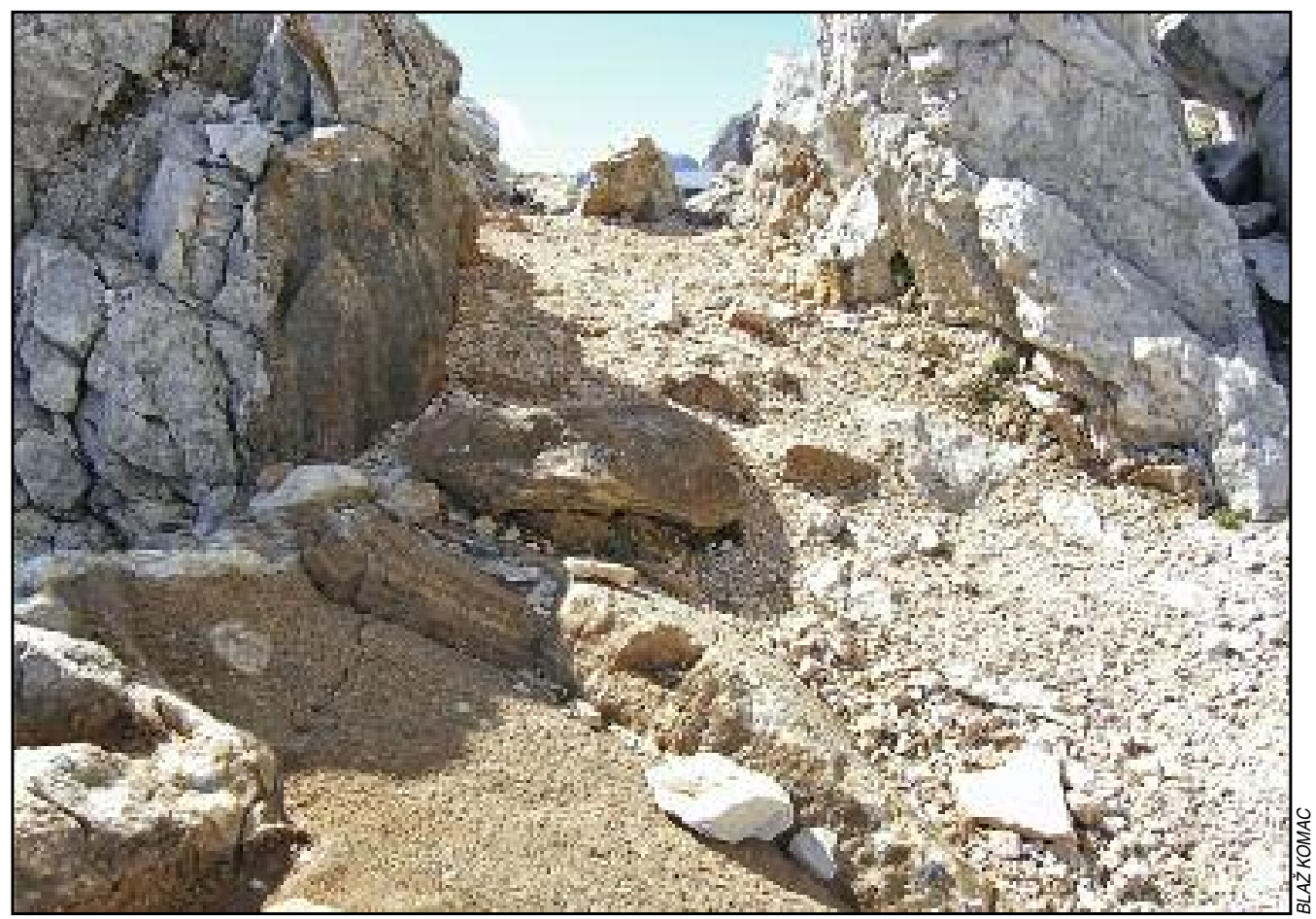

Figure 7: A former karst cave, presented by sinter accumulation, is now exposed to surface due to chemical denudation of its roof. 
glacier it has been shrinking since the Little ice age. Its surface reduced from 30 ha in 1900 and 15 ha in 1946 (Gabrovec 1998) to about 1 ha in 2009. After the withdrawal of the glacier, many karstic and other features were exposed to surface, the glacial moraines and glacial scratches being the most common. In addition to this, new relief forms came into existence. Very interesting are layers of subglacial sinter that accumulated below the glacier due to changing pressure in subglacial water environment. They are a temporary form as they are exposed to dissolution by water. If properly managed they could both become an interesting geomorphosite. Also, karst shafts that were covered by ice are now exposed to surface and accessible (Figure 6).

In other karst areas, new geomorphosites are constantly coming into existence even though karst denudation is rather slow (several $10 \mathrm{~m} / \mathrm{Ma}$ ) and only lately this process has been understood as an important part of relief formation. Karst caves and shafts open to the surface by chemical denudation so that unroofed or denuded caves form (Mihevc et al. 1998; Mihevc 2007). In this way, a former subterranean geomorphosite is slowly becoming a superficial one or the other way around: the superficial geomorphic system inherits geomorphosites from the subterranean one. This type of geomorphosites is long-lasting one, enabling us to properly protect them (Figure 7).

\section{Conclusion}

For understanding the landscape, the fact that we can predict future events to a certain extent based on knowing the natural processes (Komac 2009) and preserving the memory about them is very important. Due to its objectivised relationship with nature, modern society finds it difficult to read natural processes and geomorphosites or to recognize, accept, and transform them into a basis for taking action. This is largely the consequence of the intertwinement of the various time and space ranges in which processes in nature occur and the fact that the landscape is a dynamic network of relationships that is constantly adapting, changing, and regenerating. For this reason, it is difficult for us to understand the processes and their impacts on the landscape (Terkenli 2005), which also applies to geomorphosites.

Human perception of natural processes is often highly subjective. By subjectivity we mean especially the influence of mind image on individual and social response to natural disasters and other events. The response is therefore usually not based on objective realities, or knowledge (Natek et al. 2000; Natek 2002; Polič and Repovš 2002; Natek 2007). The development of computer science has made geomorphosites studies significantly easier but at the same time has brought about major changes. We must therefore reconsider the substance of geomorphosite research, that is, the essential importance of knowledge of the actual landscape reality and the past and current phenomena and processes in it. It is impossible to develop or properly use GIS without a good knowledge of conditions in the landscape. Computer modelling is a tool that helps us understand the processes and phenomena in the real landscape but it cannot replace them.

In spite of rather high frequency of some natural processes and numerous possibilities for providing information and keeping data, people soon forget even extreme events unless (or even though) they are recorded in newspapers and chronicles. Geomorphosites, although formed by erosion, for example, may be seen as a stable relief form.

Promptly documenting the impacts of natural processes on the landscape and on geomorphosites is very important because within a few decades all the evidence proving their actual extent could be lost and human society would therefore be unable to understand effects of recent natural processes. This includes comprehensive evaluation of the landscape reality including the geomorphosites and not merely data about them or simulations that may often be anthropocentric or may even not speak about the real world (Latour 1999, 30).

Processes do destroy natural heritage but also reshape geomorphosites. The loss of a natural heritage can result in the appearance of new geomorphosites or it can only represent a revaluation of natural heritage. Examples show that the only continuity in abiotic nature is the continuity of (geomorphic) processes. Research of geomorphosites should include studies of geomorphic processes that are related to them. In this way, geomorphosites would remain in our perception what they are per se-a marvelous natural phenomena. 


\section{References}

Batty, M. 1997: Virtual geography. Futures 29-4. Guildford. DOI: 10.1016/S0016-3287(97)00018-9

Batty, M., Cole, S. 1997: Time and space: geographic perspectives on the future. Futures 29-4. Guildford. DOI: 10.1016/S0016-3287(97)00016-5

Beresford-Jones, D., Lewis, H., Boreham, S. 2009: Linking cultural and environmental change in Peruvian prehistory: Geomorphological survey of the Samaca basin, Lower Ica valley, Peru. Catena 78-3. Amsterdam. DOI: $10.1016 /$ j.catena.2008.12.010

Caine, N. 1979: Rock weathering rates at the soil surface in an alpine environment. Catena 6-2. DOI: 10.1016/0341-8162(79)90003-1

Chorley, R. J., Schumm, S. A., Sugden, D. E. 1984: Geomorphology. London.

Erhartič, B. 2010: Geomorphosite assessment. Acta geographica Slovenica 50-2. Ljubljana. DOI: 10.3986/AGS50206

Erhartič, B., Jelenko, I. 2009: Vpliv naravnih nesreč na naravno in kulturno dediščino. Od razumevanja do upravljanja, Naravne nesreče v Sloveniji 1. Ljubljana.

Ford, D., Williams, P. 1996: Karst geomorphology and hydrology. London.

Gabrovec, M. 1998: The Triglav glacier between 1986 and 1998. Geografski zbornik 38. Ljubljana.

Gams I. 2003: Kras v Sloveniji. Ljubljana.

Hrvatin, M., Perko, D. 2009: Suitabitity of Hammond's method for determining landform units in Slovenia. Acta geographica Slovenica 49-2. Ljubljana. DOI: 10.3986/AGS49204

Hungr, O., McDougall, S., Wise, M., Cullen, M. 2008: Magnitude-frequency relationships of debris flows and debris avalanches in relation to slope relief. Geomorphology 96, 3-4. Amsterdam. DOI: 10.1016/j.geomorph.2007.03.020

Komac, B. 2009: Social memory and geographical memory of natural disasters. Acta geographica Slovenica 49-1. Ljubljana. DOI: 10.3986/AGS49107

Komac, B., Zorn, M. 2007: Pobočni procesi in človek. Geografija Slovenij 15. Ljubljana.

Komac, B., Zorn, M. 2009: Pokrajinski učinki skalnega podora v Pologu. Geografski vestnik 81-1. Ljubljana.

Latour, B. 1999: Pandora's hope: essays on the reality of science studies. Cambridge.

Lewis, C. S. 1998: Odprava človeka. Ljubljana.

Mihevc, A. 2000: Antropogene (!) influence on the doline fill - case study from Divaca karst - Western Slovenia. Karst studies and problems: 2000 and beyond. Cluj-Napoca.

Mihevc, A. 2005: Dry walls and transformed dolines - anthropogenic influence on the surface of the kras in the area of Divača, Račice and Volčji Grad. Kras - Water and life in a rocky landscape. Ljubljana.

Mihevc, A. 2007: The age of karst relief in west Slovenia. Acta carsologica 36-1. Ljubljana.

Mihevc, A., Slabe, T., Šebela, S. 1998: Denuded caves - an inherited element in the karst morphology; the case from Kras. Acta carsologica 27-1. Ljubljana.

Mikoš, M., Fazarinc, R., Ribičič, M. 2006: Sediment production and delivery from recent large landslides and earthquake-induced rock falls in the Upper Soča River Valley, Slovenia. Engineering Geology 86, 2-3. Amsterdam. DOI: 10.1016/j.enggeo.2006.02.015

Natek, K. 2002: Ogroženost zaradi naravnih procesov kot strukturni element slovenskih pokrajin. Dela 18. Ljubljana.

Natek, K. 2007: Geografske dimenzije naravnih nesreč in varstva pred njimi. Dela 28. Ljubljana.

Natek, K., Marušič, J., Polič, M., Kos, D., Klemenčič, M., Kučan, A., Ule, M. 2000: Spoznavni zemljevid Slovenije. Ljubljana.

Ollier, C. 1969: Weathering. Edinburgh.

Panizza, M. 2001: Geomorphosites: Concepts, methods and examples of geomorphological survey. Chinese Science Bulletin 46, 4-6. Beijing. DOI: 10.1007/BF03187227

Polič, M., Repovš, G. (eds.) 2002: Spoznavni zemljevid Slovenije. Ljubljana.

Radinja, D. 1983: Naravne nesreče v geografski luči. Naravne nesreče v Jugoslaviji s posebnim ozirom na metodologijo geografskega proučevanja. Ljubljana.

Ramovš, A. 1983: Slapovi v Sloveniji. Ljubljana.

Reynard, E. 2005: Géomorphosites et paysages. Géomorphologie: relief, processus, environnement 3. Paris. Reynard, E., Coratza, P. 2007: Geomorposites and geodiversity: a new domain of research. Geographica Helvetica 62-3. Bern. 
Reynard, E., Fontana, G., Kozlik, L., Scapozza, C. 2007: A method for assessing »scientific« and »additional values" of geomorphosites. Geographica Helvetica 62-3. Bern.

Reynard, E. 2009: Geomorphosites: definitions and characteristics. Geomorphosites. München.

Savigear, R. A. G. 1952: Some observations on slope development in South Wales. Transactions of the Institute of British Geographers 18. Oxford. DOI: 10.2307/621019

Sparks, B. W. 1972: Geomorphology. London.

Terkenli, T. S. 2005: New landscape spatialities: the changing scales of function and symbolism. Landscape and Urban Planning 70, 1-2. Amsterdam. DOI: 10.1016/j.landurbplan.2003.10.012

Trimble, S. W., Mendel, A. C. 1995: The cow as a geomorphic agent - A critical review. Geomorphology 13, 1-4. Amsterdam. DOI: 10.1016/0169-555X(95)00028-4

Vidrih, R., Ribičič, M., Suhadolc; P. 2001. Seismogeological effects on rocks during the 12 April 1998 upper Soča Territory earthquake (NW Slovenia). Tectonophysics 330 (3-4). Amsterdam. DOI: 10.1016/ S0040-1951(00)00219-5

Wilkinson, B. 2004: People cause more soil erosion than all natural processes. Science daily. Internet: http://www.sciencedaily.com/releases/2004/11/041103234736.htm (20.1.2009).

Wolman, M. G., Miller, J. P. 1960: Magnitude and frequency of forces in gemorphic processes. The Journal of Geology 68-1. Chicago. DOI: 10.1086/626637

Zorn, M. 2009: Erosion processes in Slovene Istria - part 2: Badlands. Acta geographica Slovenica 49-2. Ljubljana. DOI: 10.3986/AGS49203

Zorn, M., Komac, B. 2008: Response of soil erosion to land use change with particular reference to the last 200 years (Julian Alps, Western Slovenia). XXIV th conference of the Danubian countries on the hydrological forecasting and hydrological bases of water management. Ljubljana. 